\title{
NYMPHICIDAL EFFECT OF VEGETAL EXTRACTS OF Annona mucosa AND Anonna crassiflora (MAGNOLIALES, ANNONACEAE) AGAINST RICE STALK STINK BUG, Tibraca limbativentris (HEMIPTERA, PENTATOMIDAE) ${ }^{1}$
}

\author{
DIONES KRINSKI² \& ANGÉLICA MASSAROLI ${ }^{3}$
}

ABSTRACT- This study aimed to verify the chloroform-methanol nymphicidal action of extracts of Annona mucosa leaves and seeds and of $A$. crassiflora seeds on second instar nymphs of rice stalk stink bug, Tibraca limbativentris. For each extract the concentrations of $0.5 \%, 1.0 \%, 2.0 \%, 4.0 \%, 8.0 \%$, and two control treatments (water and Tween $80^{\circledR}$ ) were used. The results show that the seed extracts of $A$. mucosa and $A$. crassiflora have insecticidal activity against the $T$. limbativentris nymphs with statistical significance for all concentrations when compared with controls. The seed extract of $A$. mucosa showed the higher toxicity with greater than $75 \%$ mortality at a concentration of $1.0 \%$ in the first $24 \mathrm{~h}$ after application. The leaf extract of A. mucosa presented the lowest toxicity with no more than $40 \%$ mortality. The seed extract of $A$. crassiflora showed intermediate toxicity among all the tested extracts, and the nymph's mortality exceeded $80 \%$ for the highest concentration after $120 \mathrm{~h}$ of application. Considering these results, we were able to observe that the seeds extract of $A$. mucosa may be an alternative for the control of bed bug nymphs T. limbatriventris, especially for small producers.

Index terms: inseticidal plants, biological insecticide, alternative control, phyto-insecticide.

\section{EFEITO NINFICIDA DE EXTRATOS VEGETAIS DE Annona mucosa E Annona crassiflora (MAGNOLIALES, ANNONACEAE) SOBRE O PERCEVEJO-DO-COLMO DO ARROZ, Tibraca limbativentris (HEMIPTERA, PENTATOMIDAE).}

\begin{abstract}
RESUMO - Este trabalho teve como objetivo verificar a ação ninficida dos extratos clorofórmio-metanólico de folhas e sementes de Annona mucosa e de sementes de $A$. crassiflora sobre ninfas de segundo instar do percevejo-do-colmo do arroz, Tibraca limbativentris. Para cada extrato, foram utilizadas concentrações de $0,5 \% ; 1,0 \% ; 2,0 \% ; 4,0 \% ; 8,0 \%$; e dois tratamentos-controle (Tween $80^{\circledR}$ e água). Os resultados mostram que os extratos de sementes de $A$. mucosa e de $A$. crassiflora apresentaram atividade inseticida sobre ninfas de segundo instar de T. limbativentris em todas as concentrações, quando comparadas com os controles. $\mathrm{O}$ extrato de sementes de $A$. mucosa foi o que apresentou maior toxicidade com mortalidade maior que $75 \%$ na concentração de $1,0 \%$ do extrato, nas primeiras $24 \mathrm{~h}$ após a aplicação. $\mathrm{O}$ extrato de folhas de $A$. mucosa apresentou a menor toxicidade, não ultrapassando $40 \%$ de mortalidade. O extrato de sementes de $A$. crassiflora apresentou toxicidade intermediária entre todos os extratos testados, e a mortalidade das ninfas passou dos $80 \%$ na maior concentração, após $120 \mathrm{~h}$ da aplicação. Diante destes resultados, nota-se que o extrato de $A$. mucosa pode ser uma alternativa para o controle de ninfas do percevejo $T$. limbatriventris, principalmente para pequenos produtores.
\end{abstract}

Termos para indexação: plantas inseticidas, inseticida biológico, controle alternativo.

\footnotetext{
${ }^{1}$ (Trabalho 205-13). Recebido em: 20-05-2013. Aceito para publicação em: 05-02-2014. V Congresso Internacional \& Encontro Brasileiro sobre Annonaceae: do gene à exportação (19 a 23 de Agosto de 2013). Botucatu-SP.

${ }^{2}$ Doutorando em Zoologia. Mestre em Ecologia e Conservação da Biodiversidade. Universidade Federal do Paraná (UFPR), Programa de Pós-Graduação em Zoologia, Departamento de Zoologia, Bairro Jardim das Américas, Caixa Postal 19020, 81531-980, Curitiba, PR, Brazil. Email: diones.krinski@ufpr.br

${ }^{3}$ Mestre em Zoologia. Bióloga. Universidade Federal do Paraná (UFPR), Programa de Pós-Graduação em Zoologia, Departamento de Zoologia, Bairro Jardim das Américas, Caixa Postal 19020, 81531-980, Curitiba, PR, Brazil.

Email: angelicamassaroli@gmail.com
} 


\section{INTRODUCTION}

Rice is the basic food for more than half of the world's population and presents one of the best nutritional balancing, responsible for providing $20 \%$ and $15 \%$ of the energy and protein needed for human nourishment (AZAMBUJA et al., 2004). During its cultivation a rice crop can be affected by invasive plants, phytophagous insects and diseases that can reduce significantly the productivity and grain quality up to $90 \%$ (FERREIRA et al., 1997; MARTINS et al., 2009). Among the main pests that attack rice crop the stink bug Tibraca limbativentris Stal, 1860 (Hemiptera: Pentatomidade), also known as brown stink bug, rice stem bug, rice stalk stink bug and stink bug large of rice, is one of the most important pests for rice crops in Brazil (FERREIRA et al., 1986). This species has a wide geographical distribution in the Neotropics (FERNANDES e GRAZIA, 1998) occurring in all regions of rice cultivation in Latin America (MARTINS et al., 2004). It is considered a pest in countries such as Argentina, Brazil, Colombia, Ecuador, Peru, Dominican Republic and Venezuela (PANTOJA et al., 2007).

The rice stalk stink bug is a hard insect pest to control in all rice production areas in Brazil, regardless of the production system used(MARTINS et al., 2009). According to Souza et al. (2009), the most used way to control T. limbativentris is through chemical products, and active registered ingredients are the phytosanitary pesticide system (AGROFIT) composed of tiometoxam (neonicotinoid), cyfluthrin (pyrethroid), lambda-cyhalothrin (pyrethroid) and malotina (organophosphate) (MAPA, 2010).

Considering the current effects caused by the use of chemicals in agriculture, a viable alternative for the control of this insect would be to use insecticidal plants extracts, which have low toxicity and little persistence in the environment (COSTA et al., 2004). In this context, plants of Annonaceae family come up as a promising alternative for general pest control, since acetogenins can be found within their composition, which are compounds that have a high insecticidal potential (ALALI et al., 1999). Some studies reporting the insecticidal properties of Annonaceae were primarily tested to control insect disease vectors such as mosquitoes (Diptera) and several species of triatomine bugs (Hemiptera, Reduviidae) (CARNEIRO et al., 2011; 2013; COSTA et al., 2012; DILL et al., 2012; MORAES et al., 2011). Researches that reported the Annonaceou's bioactivity on mortality of stink bugs (mainly on pentatomids) are nonexistent or incipient, and thus must be further studied. Therefore, due to the necessity of seeking alternative methods that stipulate a less impactful agriculture on the environment, this study aims to verify the nymphicidal action of chloroform-methanol extracts of Annona mucosa leaves and seeds and of Annona crassiflora seeds on second instar nymphs of rice stalk stink bug, $T$. limbativentris.

\section{MATERIAL AND METHODS}

\section{Plant material and preparation of extracts}

- The plant species used on bioassays were Annona mucosa and $A$. crassiflora (Annonaceae). Fruits and leaves of $A$. mucosa were collected in the urban area of Tangará da Serra-MT and fruits of $A$. crassiflora in the Cerrado area, both in July 2012. Exsicates of these species were deposited at TANG Herbarium of the Universidade do Estado de Mato Grosso, campus of Tangará da Serra (UNEMAT/CUTS). To obtain the extracts, plant parts (seeds and leaves) were collected, dried in forced circulation stove air at $40^{\circ} \mathrm{C}$ for $72 \mathrm{~h}$. The dried material was triturated in a grinder type knife and sent to the Laboratory of Carbohydrate Chemistry, at the Universidade Federal do Paraná (UFPR), where the de-lipidification during 3 days with organic solvents such as chloroformmethanol (2:1) using a soxhlet extractor apparatus warmed at $60^{\circ} \mathrm{C}$ until exhaustion (when there had no more material for extraction). The extracted material was rota-evaporated at $40^{\circ} \mathrm{C}$ to remove the solvent and to obtain the crude extract. From these extracts, dilutions were made at the concentrations used in the bioassays.

Collection of nymphs - The nymphs were obtained from eggs laid by females of T. limbativentris established at greenhouse located at The Brazilian Agricultural Research, National Research Center of Rice and Beans (EMBRAPA/CNPAF), Santo Antônio de Goiás/GO, Brazil $\left(6^{\circ} 28^{\prime} \mathrm{S}\right.$; 49 $9^{\circ} 17^{\prime} \mathrm{W}$; $823 \mathrm{~m})$. The egg-nymph development has been monitored daily, from hatching to the 2 nd instar. In the bioassays there were used 2 nd instar nymphs up to $24 \mathrm{~h}$. This nymphal stage was used considering that within this period of development that the nymphs begin to attack the stalks of rice. And from this instar the nymphs begin to migrate for off the colonies (which are usually in the leaves) into the plant stems. This movement blocks further strategies to control this insect pest in subsequent instars (FERREIRA et al., 1997). 
Bioassay - The bioassay was performed at the Laboratory of Entomology in EMBRAPA/CNPAF. We used a completely randomized design with five treatments and two controls with ten repetitions each containing ten 2 nd instar nymphs of the stink bug T. limbativentris. For each extract that was used the concentrations varied from $0.5 \%, 1.0 \%, 2.0 \%, 4.0 \%$ and $8.0 \%$, one including a negative control with the solubilizer Tween $80^{\circledR}(10 \%)$ and another negative control containing only water. For each concentration topical applications of $2 \mu \mathrm{L}$ were made with the assistance of a micropipette in the dorsum of each insect. After application of the extract, the nymphs were placed in plastic pots $(245 \mathrm{ml})$ with a stem of rice for nourishment- The stems were changed every two days. The nymphs remained in climatized room with temperatures of approximately $25 \pm 2{ }^{\circ} \mathrm{C}$, relative humidity of $75 \pm 0.60 \%$ and photoperiod of $14 \mathrm{~h}$. The mortalty evaluation was performed daily and the live nymphs were evaluated until they reached the 3 rd instar. Data from the experiment were subjected to analysis of variance (ANOVA) and the means were compared by the Scott Knott test at 5\% probability using the SASM software (CANTERI et al., 2001). The lethal concentration to kill 50\% and $90 \%$ of insects (LC50 and LC90) and the confidence intervals (CI) were evaluated by Probit analysis using the Statistica 7 software.

\section{RESULTS AND DISCUSSION}

The results of this study show that seed extracts of $A$. mucosa, and A. crassiflora exhibited insecticidal activity against 2 nd instar nymphs of $T$. limbativentris and were statistically different in all concentrations when compared to controls $(\mathrm{p}<0.01)$. However, the leaves extract of $A$. mucosa did not show insecticidal activity against insects in the first days after application, although mortality of nymphs has increased over time (Table 1).

Many studies have demonstrated that several species of plants of the Annonaceae family have insecticidal activity against several groups of arthropods (Acari, Blattodea, Coleoptera, Diptera, Hymenoptera, Hemiptera/Homopetera, Hemiptera/ Heteroptera, Lepidoptera) (CASTILLO-SÁNCHES et al., 2010; BROGLIO-MICHELETTI et al., 2009; MAGADUM et al., 2009). Researches using Annonaceae in control of triatomine bugs were developed by Carneiro et al. (2011, 2013), using extracts of Annona coriacea against Rhodnius neglectus (Hemiptera: Reduviidae) and Parra-Henao et al. (2007) using the extract of A. muricata on Rhodnius prolixus and Rhodnius pallescens.
However, studies on the bioactivity of Annonaceae extracts about stink bugs pentatomids are still scarce, and the first studies performed in Brazil were made by Souza et al. (2007) using A. coriacea and Cordeiro (2007) with extracts of A. crassiflora, both on stink bug Dichelops melacanthus (Hemiptera: Pentatomidae). The most recent works are of Magalhães et al. (2011) and Bandeira et al. (2011) that evaluated the insecticide effect of A. mucosa extract against the brown stink bug, Euschistus heros (Hemiptera: Pentatomidae). This demonstrates the importance of increasing the studies using these plants against other insect pests, as conducted in this work with rice stalk stink bug nymphs, $T$. limbativentris.

In this study, the seed extracts of $A$. mucosa showed higher mortality at all concentrations when compared with the seed extracts of $A$. crassiflora, controling more than $75 \%$ of $T$. limbativentris nymphs of at the concentration of $1.0 \%$ after the first 24 hours, reaching $88 \%$ for this same concentration after 5 days from the application of the extract. Additionally, concentrations of 2.0, 4.0 and $8.0 \%$ killed within 24 h respectively 90,92 and $100 \%$ of nymphs. This pattern was similar in the evaluations of 72 and 120 hours after application of the extract (Table 1).

Similar results were observed by Cordeiro (2007), using hexane extract of $A$. crassiflora on $D$. melacanthus nymphs and $E$. heros at concentrations of 8.0, 4.0 and $2.0 \%$, achieving mortality of 98,90 and $98 \%$ respectively for $D$. melacanthus and 64, 56 and $56 \%$ for E. heros respectively. In another study, Magalhães et al. (2011) used hexanic extract of $A$. mucosa seeds and verified $100 \%$ mortality of $E$. heros nymphs at concentrations of 2.0, 4.0 and $8.0 \%$ and $67.5 \%$ in the concentration of $1.0 \%$, corroborating with the data shown in this research. Studying other species of Annonaceae, Souza et al. (2007) found the insecticidal activity of ethanolic and hexanic extracts of A. coriacea seeds on D. melacanthus, with $100 \%$ mortality with 4.0 and $8.0 \%$ for ethanol extract and 78,86 and $68 \%$ with $8.0,4.0$ and $2.0 \%$, respectively with the hexanic extract. This demonstrates that different species of Annonaceae can be used to control stink bugs from differents crops.

The leaves extracts of $A$. mucosa were less efficient when compared to extracts of seeds of both species used on the bioassays, although it showed differences among different concentrations and the controls (Table 1). Most research with Annonaceae use mainly extracts from seeds because the knowledge of some bioactive compounds that are present in higher quantities in these plant 
parts, especially from the acetogenins class, are promising for obtaining substances with insecticidal properties (CASTILLO-SÁNCHEZ et al., 2010; NASCIMENTO et al., 2003; ALALI et al., 1999). However, studies such as those of Cruz-Estrada et al. (2013), using extracts of Annona squamosa leaves showed high mortality rate of eggs and nymphs of whitefly, Bemisia tabaci (Hemiptera: Aleyrodidae), indicating that other plant parts such as Annonaceae leaves, are also sources of bioactive substances potential insecticide.

Therefore, is likely that the leaves extracts of A. mucosa did not present high mortality rate of $T$. limbativentris nymphs due to possible variation in the amount of acetogenins amount in the different plant parts (intra and inter-specific), showing that the leaves have less bioactive compounds that the seeds. Such is supported when the lethal concentrations (LC50 and LC90) found when the leaves extracts of $A$. mucosa, were taken into consideration (Table 1). Different from what was observed for the seeds extracts of $A$. mucosa where the LC50 values were lower when compared to the leaf extracts and also with the extract of $A$. crassiflora seeds. These findings highlights the high toxicity of seeds extract of $A$. mucosa on T. limbativentris nymphs, thereby causing the mortality of the insects with a small quantity of the extract (Table 1).

The high percentage of $T$. limbativentris nymphs' mortality within the first $24 \mathrm{~h}$ after application of the seeds extract of $A$. mucosa may be due to the excess of acetylcholine in the body of the insect caused by acetylcholinesterase inhibition, since it was observed that some nymphs "trembled" soon after the application of the extract, rapidly dying. Considering that the excess of acetylcholine causes something like a "short circuit" or excessive electrical discharge in the nervous system of the insect, this interferes in the balance of the body, causing the death of the insect by hyperexcitation (NELSON and COX, 2011).

Thus, the increase in T. limbativentris nymph's mortality during all the evaluation days with seed extracts of $A$. crassiflora might be a consequence of inanition since the nymphs do not feed or to the decrease in their feeding needs (feeding deterrence). Although this characteristic was not evaluated during the bioassays, authors such as Álvares-Colom et al. (2007) have reported that the effect of inanition is due to the use of Annonaceae extracts, especially when considering that the acetogenins present in these plants, which are potent inhibitors of mitochondrial complex I in NADH systems:oxidase of the plasma membrane, inducing apoptosis (programmed cell death) being thus a potential substance for use as pesticide (GONZÁLEZ-COLOMA et al., 2002; JOHNSON et al., 2000). These results corroborate whit those reported by Oliveira e Pereira (2009) that evaluated the antifeedant activity of $A$. crassiflora on adult brown stink bug, E. heros.

Also it was observed that some $T$. limbativentris nymphs lost their mobility after the use of extracts and this might also be a response of the acetogenins present in extracts of these species. It is known that the action of acetogenins, by contact or ingestion, interfere in sodium channels which is regulated by voltage, and this changes the balance of sodium and potassium, which impedes the normal nerve transmission, causing the insect paralysis followed by death ("knockdown") (HOLAN, 1969; COATS, 1990).

Considering these results, we have observed that the seed extract of $A$. mucosa might seen as an alternative for the control of T. limbatriventris nymphs, especially for small producers. However, further studies are needed in other developmental stages of the stink bug (eggs and adults, for example), as well as field research to check whether the same patterns found in laboratory bioassays are maintained under field contitions. Also it is to perform necessary additional researches with the aim of fractionate, isolate and identify the bioactive substances to be employed in the future for the development of new and promising biological insecticides for use in the integrated management of rice stalk stink bug and other insect pests. 


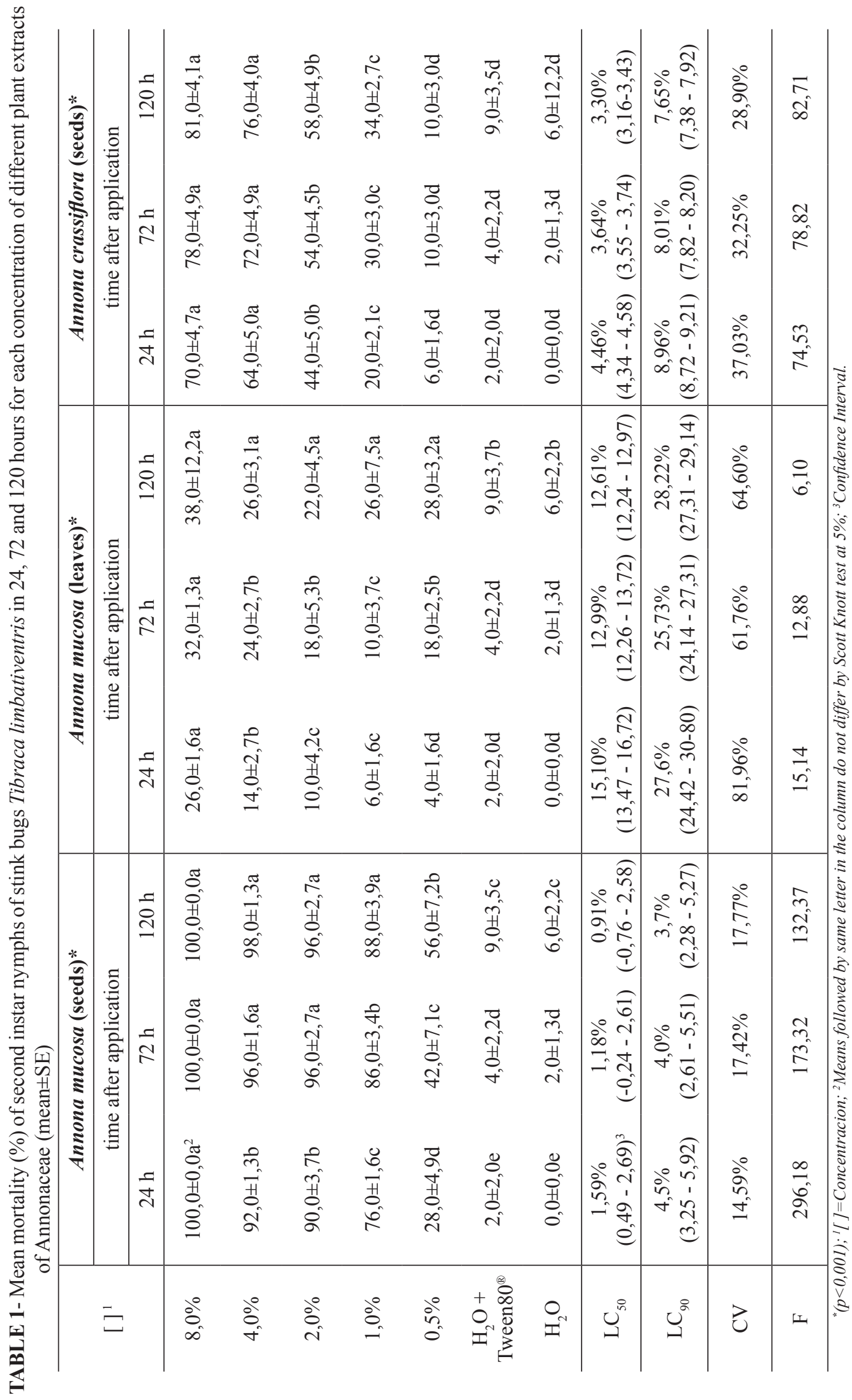




\section{CONCLUSIONS}

1 - The seed extracts of Annona mucosa show high toxicity on the second instar of Tibraca limbativentris nymphs with mortality greater than $75 \%$ at an extract concentration of $1.0 \%$ already in the first $24 \mathrm{~h}$ after application.

2 - The leave's extracts of $A$. mucosa show low toxicity for 2 nd instar of $T$. limbativentris nymphs and mortality did not exceed $40 \%$ even after $120 \mathrm{~h}$ of application.

3 - The seed extracts of Annona crassiflora present intermediate toxicity among all the extracts tested and mortality of nymphs exceeded $80 \%$ at the highest concentration after $120 \mathrm{~h}$ of applying the extract.

\section{ACKNOWLEDGEMENTS}

The authors acknowledge the Programa de Pós-graduação em Zoologia da Universidade Federal do Paraná (UFPR), for financial support; the researchers Dr. José Alexandre Freitas Barrigossi (EMBRAPA/CNPAF), Dr. Guilherme Lanzi Sassaki and Alexsandro Nogueira from Department of Biochemistry, Laboratory of Chemistry of Carbohydrates (UFPR) for their assistance during this study. We thank to the National Council for Scientific and Technological Development (CNPq) and also to CAPES (Brazilian Coordination for the Improvement of Higher Education Personnel) for providing the scholarships.

\section{REFERENCES}

ALALI, F. Q.; LIU, X.; MCLAUGHLIN, J. L. Annonaceous Acetogenins: Recent Progress. Journal of Natural Products, Columbus, v. 62, n.3, p.504-540, 1999 .

ÁlVAREZ-COLOM, O.; NESKE, A., POPICH, S.; BARDÓN, A. Toxic effects of annonaceous acetogenins from Annona cherimolia (Magnoliales: Annonaceae) on Spodoptera frugiperda (Lepidoptera: Noctuidae). Journal of Pest Science, New York, v. 80, n.1, p.63-67, 2007.

AZAMBUJA, I. H. B.; VERNETTI-JUNIOR, F. J.; MAGALHÃES-JUNIOR, A. M. (Ed.). Arroz irrigado no Sul do Brasil. Brasília: Embrapa Informação Tecnológica, 2004.
BANDEIRA, W. T.; PEREIRA, M. J. B.; SILVA, V. P.; PITON, L. P. Bioatividade do extrato bruto de Annona mucosa (Annonaceae) sobre ninfas do percevejo marrom Euschistus heros (Hemiptera: Pentatomidae) In: CONGRESSO DE INICIAÇÃO CIENTÍFICA, 4., 2011, Cáceres. Anais... Cáceres: Pró-Reitoria de Pesquisa e Pós-Graduação, 2011. v.7. CD-ROM.

BROGLIO-MICHELETTI, S. M. F.; VALENTE, E. C. N.; SOUZA, L. A.; DIAS, N. S.; ARAÚJO, A. M. N. Extratos de plantas no controle de Rhipicephalus (Boophilus) microplus (Canestrini, 1887) (Acari: Ixodidae) em laboratório. Revista Brasileira de Parasitologia Veterinária, Jaboticabal, v. 18, n.4, p.44-48, 2009.

CARNEIRO, A. P.; PEREIRA, M. J. B.; GALBIATI, C. Biocide Activity of Annona coriacea extract on fourth and fifth instars nymphs and adults of the vector Rhodnius neglectus (Hemiptera, Reduviidae). Revista de Biologia Tropical, San José, v. 61, n.1, p.419-427, 2013.

CARNEIRO, A. P.; PEREIRA, M. J. B.; GALBIATI, C. Efeito biocida do extrato de Annona coriacea Mart 1841 sobre ovos e ninfas recém-eclodidas do vetor da doença de Chagas Rhodnius neglectus Lent 1954 (Hemiptera, Reduviidae). Neotropical Biology and Conservation, São Leopoldo, v. 6, n.2, p.131-136, 2011.

CASTILLO-SÁNCHEZ, L. H. C.; JIMÉNEZOSORNIO, J. J.; DELGADO-HERRERA, M. A. Secondary metabolites of the Annonaceae, Solanaceae and Meliaceae families used as biological control of insects. Tropical and Subtropical Agroecosystems, Yucatán, v. 12, n.3, p.445-462, 2010.

COATS, J. R. Mechanisms of toxic action and structure-activity relationships for organochiorine and synthetic pyrethroid insecticides. Environmental Health Perspectives, New York, v. 87, p.255-262, 1990.

CORDEIRO, J. R. Atividade inseticida de extratos das sementes de Annona sp. em ninfas de Dichelops melacanthus (Dallas, 1851) e Euschistus heros (Fabricius, 1794) (Hemiptera: Pentatomidae). 2007. Monografia (Trabalho de Gradução em Agronomia) - Universidade do Estado de Mato Grosso, Cáceres, 2007. 
COSTA, E. L. N.; SILVA, R. F. P.; FIUZA, L. M. Efeitos, aplicações e limitações de extratos de plantas inseticidas. Acta Biologica Leopoldensia, São Leopoldo, v. 26, n.2, p.173-185, 2004.

COSTA, M. S.; PINHEIRO, D. O.; SERRÃO, J. E.; PEREIRA, M. J. B. Morphological changes in the midgut of Aedes aegypti L. (Diptera: Culicidae) larvae following exposure to an Annona coriacea (Magnoliales: Annonaceae) extract. Neotropical Entomology, New York, v. 41, n. 4, p.311-314, 2012.

CRUZ-ESTRADA, A.; GAMBOA-ÂNGULO. M.; BORGES-ARGÁEZ, R.; RUIZ-SÁNCHEZ, E. Insecticidal effects of plant extracts on immature whitefly Bemisia tabaci Genn. (Hemiptera: Aleyroideae). Electronic Journal of Biotechnology, Valparaíso, v. 16, n.1, 2013. Disponível em: $<\mathrm{http} / /$ dx.doi.org/10.2225/vol16-issue1-fulltext-6> Acesso em: 21 abr. 2013.

DILL, E. M.; PEREIRA, M. J. B.; COSTA, M. S. Efeito residual do extrato de Annona coriacea sobre Aedes aegypti. Arquivos do Instituto Biológico, São Paulo, v. 79, n.4, p.595-601, 2012. Disponível em: $<$ http://www.biologico.sp.gov.br/docs/arq/v79_4/ dill.pdf> Acesso em: 21 abr. 2013.

FERNANDES, J. A. M.; GRAZIA, J. Revision of the genus Tibraca Stal (Heteroptera, Pentatomidae, Pentatominae). Revista Brasileira de Zoologia, Curitiba, v. 15, n. 4, p, 1049-1060, 1998.

FERREIRA, E.; MARTINS, J. F. S.; RANGEL, P. H. N.; CUTRIM, V. A. Resistência de arroz ao percevejo do colmo. Pesquisa Agropecuária Brasileira, Brasília, v.21, n.5, p.565-569, 1986.

FERREIRA, E.; ZIMMERMANN, F. J. P.; SANTOS, A. B.; NEVES, B. P. O percevejo do colmo na cultura do arroz. Goiânia: EMBRAPA-CNPAF, 1997. 44p. (Documentos, 75)

GONZÁLEZ-COLOMA, A.; GUADAÑO, A.; DE INÉS, C.; MARTÍNEZ-DÍAZ, R.; CORTÉS, D. Selective action of acetogenin mitochondrial Complex I inhibitors. Zeitschrift für Naturforschung C, Tuebingen, v. 57C, n.1/2, p.1028-1034, 2002.
JOHNSON, H. A.; ORBELIES, N. H.; ALALI, F. Q.; McLAUGHLIN, J. L. Thwarting resistence: annonaceous acetogenins as new pesticidal and antitumor agents. In: CUTLER, S. J.; CUTLER, H. G. (Ed.). Biologically active natural products: pharmaceuticals. Washington: CRC Press, 2000. p.173-184.

MAGADUM, S.; MONDAL, D. B.; GHOSH, S. Comparative efficacy of Annona squamosa and Azadirachta indica extracts against Boophilus microplus Izatnagar isolate. Parasitology Research, New York, v. 105, n.4, p.1085-1091, 2009.

MAGALHÃES, F. B.; SILVA, V. P.; PEREIRA, M. J. B.; SOUZA, P. T.; DALL'OGLIO, E. L. Efeito do extrato hexânico de Annona mucosa Jacq. (Annonaceae) na mortalidade de ninfas do percevejo Euschistus heros F. (Heteroptera: Pentatomidae). In: CICLO DE ESTUDOS EM BIOLOGIA DE TANGARÁ DA SERRA, 2.; CICLO NACIONAL DE ESTUDOS DE BIOLOGIA, 1., 2011, Tangará da Serra. Anais...

MAPA - Ministério da Agricultura, Pecuária e Abastecimento. Agrofit-sistema de agrotóxicos fitossanitários. 2010. Disponível em: $<\underline{\mathrm{http}: / /}$ extranet.agricultura.gov.br/agrofit_cons/principal agrofit_cons $>$. Acesso em: 21 abr. 2013.

MARTINS, J. F. S.; BARRIGOSI, J. A. F.; OLIVEIRA, J. V.; CUNHA, U. S. Situação do manejo integrado de insetos-praga na cultura do arroz no Brasil. Pelotas: Embrapa Clima Temperado, 2009. 40 p. (Documentos, 290).

MARTINS, J. F. S.; GRÜTZMACHER, A. D.; CUNHA, U. S. Descrição e manejo integrado de insetos-praga em arroz irrigado. In: GOMES, A. S.; MAGALHÃES JÚNIOR, A. M. de. (Ed.). Arroz irrigado no sul do Brasil. Brasília: Embrapa Informação Tecnológica, 2004. p.635-675.

MORAES, J. M.; PEREIRA, M. J. B.; COSTA, M. S.; GALBIATI, C.; SILVA, E. P. Avaliação da atividade de Annona coriacea (Annonaceae) sobre pupas e adultos de Aedes aegypti (Diptera:Culicidae) em laboratório. Revista de Agricultura, Piracicaba, v. 86, p.56-60, 2011. 
NASCIMENTO, F. C.; BOAVENTURA, M. A. D.; ASSUNÇÃO, A. C. S.; PIMENTA, L. P. S. Acetogeninas de Anonáceas isoladas de folhas de Rollinia laurifolia. Química Nova, São Paulo, v. 26, n.3, p.319-322, 2003.

NELSON, D. L.; COX, M. M. Principios de bioquímica de Lehninger: edição comemorativa 25 anos. 5. ed. Porto Alegre: Artmed, 2011. 1304p.

OLIVEIRA, A. C.; PEREIRA, M. J. B. Efeito antialimentar do extrato metanólico de Annona crassiflora Mart. sobre o percevejo marrom Euschistus heros (Fabr. 1798) (Heteroptera:Pentatomidae). Revista Brasileira de Agroecologia, Porto Alegre, v. 4, n.2, p.2633-2636, 2009.

PANTOJA, A.; TRIANA, M.; BASTIDA, H.; GARCIA, C.; MEJÍA, O. I.; DUQUE, M. C. Damage by Tibraca limbativentris (Hemiptera: Pentatomidae) to rice in Southwestern Colombia. Journal of Agriculture of the University of Puerto Rico, Puerto Rico, v. 91, n.1/2, p.11-18, 2007.
PARRA-HENAO, G.; PAJÓN, C. M. G.; TORRES, J. M. C. Actividad insecticida de extractos vegetales sobre Rhodnius prolixus y Rhodnius pallescens (Hemiptera: Reduviidae). Boletín de Malariología y Salud Ambiental, Maracay, v. 47, p.125-137, 2007.

SOUZA, E. M.; CORDEIRO, J. R.; PEREIRA, M. J. B. Avaliação da atividade inseticida dos diferentes extratos das sementes de Annona coriacea sobre Dichelops melacanthus (Dallas, 1851). In: Resumos do V CBA - Manejo de Agroecossistemas Sustentáveis. Revista Brasileira de Agroecologia, Porto Alegre, v. 2, n.2, p.1107-1110, 2007.

SOUZA, J. R.; FERREIRA, E.; CARGNELUTTI FILHO, A.; BOIÇA JR, A. L.; CHAGAS, E. F.; MONDEGO, J. M. Divergência genética de cultivares de arroz quanto à resistência a Tibraca limbativentris Stål (Hemiptera: Pentatomidae). Neotropical Entomology, New York, v. 38, n.5, p.671-676, 2009. 